\title{
FOOD/DRUG AND DRUG/NUTRIENT INTERACTIONS: What You Should Know About Your Medications ${ }^{1}$
}

Linda B. Bobroff, Ashley Lentz, and R. Elaine Turner²

\section{Introduction}

Medications, both prescription and over-the-counter, are used every day to treat acute and chronic illness. Research and technology constantly improve the drugs we have available and introduce new ones. Medications can help people live healthy lives for a prolonged period. Although medicines are prescribed often, it is important to realize that they must still be used with caution.

Foods, and the nutrients they contain, can interact with medications we take. This can cause unwanted effects. A food/drug interaction occurs when a food, or one of its components, interferes with the way a drug is used in the body. A drug/nutrient interaction occurs when a drug affects the use of a nutrient in the body.

This fact sheet describes common food/drug and drug/nutrient interactions. We hope this will help you see the potential for interactions and learn to avoid them. Be sure to talk with your doctor and pharmacist to get the maximum benefits from your medications.

\section{Risk Factors}

Risk for food/drug and drug/nutrient interactions can be affected by many factors such as:

- age

- gender

- medical history

- body composition

- nutritional status

- number of medications used

\section{How Drugs React in the Body}

In order to understand food/drug and drug/nutrient interactions, it's important to understand how drugs work in the body. There are four stages of drug action for medicines taken by mouth:

Stage 1. The drug dissolves into a useable form in the stomach.

Stage 2. The drug is absorbed into the blood and transported to its site of action.

Stage 3. The body responds to the drug and the drug performs a function.

Stage 4. The drug is excreted from the body either by the kidney, the liver, or both.

1. This document is FCS8092, one of a series of the Department of Family, Youth and Community Sciences, Florida Cooperative Extension Service, Institute of Food and Agricultural Sciences, University of Florida. First Published: March 1999. Revised dates: November 2008; May 2009. Please visit the EDIS Web site at http://edis.ifas.ufl.edu.

2. Linda B. Bobroff, PhD, RD, LD/N, professor, Department of Family, Youth, and Community Sciences; Ashley Lentz, MS, former Graduate Student, Food, Science and Human Nutrition Department; and R. Elaine Turner, PhD, RD, Professor and Associate Dean, College of Agricultural and Life Sciences, Institute of Food and Agricultural Sciences, University of Florida, Gainesville, FL 32611. We thank Paul Doering, UF College of Pharmacy for his review and Laurie Walker, BS, Food Science and Human Nutrition Department for her contributions. 
Not all medications are taken by mouth. Still, they are all transported to the site of action. Effects of drug/nutrient and food/drug interactions vary according to:

- type of medication

- form of drug (pill, liquid, etc.)

- dosage

- site of absorption (mouth, stomach, intestine)

- route of administration (oral, intravenous, etc.)

\section{Definitions}

Absorption: the passage of substances from the GI tract into the blood.

Excretion: removal of drugs or nutrients from the body.

Intravenous: within the blood.

Nutritional status: nutrition-related health.

Transport: movement of a substance from one site in the body to another.

\section{Food/Drug Interactions}

Foods can interfere with the stages of drug action in a number of ways. The most common effect is for foods to interfere with drug absorption. This can make a drug less effective because less gets into the blood and to the site of action. Second, nutrients or other chemicals in foods can affect how a drug is used in the body. Third, excretion of drugs from the body may be affected by foods, nutrients, or other substances.

With some drugs, it's important to avoid taking food and medication together because the food can make the drug less effective. For other drugs, it may be good to take the drug with food to prevent stomach irritation.
Alcohol can affect many medications. Always check with your pharmacist about possible effects of alcohol on your medication.

\section{Grapefruit Juice and Drugs}

Grapefruit juice contains a compound that increases the absorption of some drugs. This can enhance their effects. This compound is not found in other citrus juices.

It's best to not take medications with grapefruit juice. Drink it at least two hours away from when you take your medication. If you often drink grapefruit juice, talk with your pharmacist or doctor before changing your routine.

See Table 1 for specific examples of food/drug interactions.

\section{Drug/Nutrient Interactions}

It is also possible for drugs to interfere with a person's nutritional status. Some drugs interfere with the absorption of a nutrient. Other drugs affect the body's use and/or excretion of nutrients, especially vitamins and minerals. If less of a nutrient is available to the body because of these effects, this may lead to a nutrient deficiency.

Sometimes drugs affect nutritional status by increasing or decreasing appetite. This affects the amount of food (and nutrients) consumed. Some specific examples of drug/nutrient interactions are given in Table 2.

\section{The Different Groups of Medicines}

Drugs are grouped into classes based on illnesses for which they are prescribed. They can also be grouped in other ways, such as 
their chemical make-up or actions in the body. Different foods can interact with more than one class of drugs.

Table 3 is a list of 14 drug classes and the uses for each. If you take medication in one of these classes, be aware of potential food/drug and drug/nutrient interactions. If you aren't sure which classes your medicines fall into, ask your doctor or pharmacist.

\section{Analgesic}

Analgesics are drugs that relieve pain. Analgesics often cause stomach irritation. It's a good idea to take analgesics, like aspirin, with food. A full stomach lowers the risk for stomach irritation.

\section{Antacid, Acid Blocker}

Antacids neutralize stomach acid, and acid blockers reduce stomach acid production. Long term use of these drugs may lead to certain nutrient deficiencies. This is because stomach acid is important in the digestion and/or absorption of nutrients.

Older people produce less stomach acid, which leads to low absorption of vitamin $\mathrm{B}_{12}$. Regular use of antacids or acid blockers lower $\mathrm{B}_{12}$ absorption even more. Vitamin $\mathrm{B}_{12}$ supplements may be needed in this situation.

\section{Antibiotic}

Antibiotics are used to treat bacterial infections. There are many different types of antibiotics. Some antibiotics decrease the synthesis of vitamin $\mathrm{K}$ by the bacteria normally found in our intestines. Vitamin $\mathrm{K}$ is important for normal blood clotting.

Tetracycline antibiotics bind to calcium found in dairy products. This can decrease the absorption of the antibiotic.
Other drugs like penicillin and erythromycin are most effective when taken on an empty stomach. This is because they may be partially destroyed by stomach acid when taken with food. However, food can reduce the chance of stomach irritation from these drugs. Ask your pharmacist if you should take your particular antibiotic with or without food.

\section{Anticoagulant}

Anticoagulants slow the process of blood clotting. This can decrease risk of strokes in patients whose blood tends to clot too easily. These drugs, like warfarin (Coumadin), work by interfering with the use of vitamin $\mathrm{K}$ in blood clotting.

People taking these anticoagulants should be consistent in the amount of vitamin K they get from foods. It's very important to avoid eating large amounts of foods high in vitamin $\mathrm{K}$. Rich sources of vitamin K include liver, and green vegetables such as broccoli, spinach and other leafy greens.

\section{Anticonvulsant}

Anticonvulsant drugs help control seizures. Phenytoin (Dilantin), phenobarbital and primidone may cause diarrhea and a decrease in appetite. This can decrease the availability of many nutrients.

These drugs also increase the use of vitamin $\mathrm{D}$ in the body. This means that less vitamin $\mathrm{D}$ is available for important functions such as calcium absorption. Vitamin D supplements may be needed.

Some anticonvulsants also interact with the B vitamin folic acid. When drug therapy is started, folic acid levels in the body decrease. Because folic acid supplements affect blood levels of the drug, folate supplementation must be supervised by a doctor. 


\section{Antihistamine}

Antihistamines are used to treat allergies. Many of these drugs often cause drowsiness. They may also increase the appetite, which can lead to weight gain. Increased physical activity can help reduce weight gain. Alcohol can cause an even greater increase in drowsiness caused by antihistamines like diphenhydramine (Benadryl), chlorpheniramine (Chlor-Trimeton), and other over-the-counter drugs containing antihistamines.

\section{Anti-inflammatory}

Anti-inflammatory medication is prescribed to patients for a number of problems such as chronic joint pain, headaches, and arthritis. Long-term use may lead to stomach irritation and eventually ulcers. These medications should be taken with food.

\section{Blood Pressure Lowering Drugs}

Antihypertensives are used to control high blood pressure. This group of medications is widely used throughout the United States due to the large number of people with high blood pressure.

These medications can affect body levels of minerals such as potassium, calcium, and zinc. For patients with diabetes, these drugs can cause problems in controlling blood sugar. In addition, natural licorice, found in some imported candies, causes salt and water retention. This can lead to an increase in blood pressure.

\section{Cancer Drugs}

Antineoplastic agents are used to treat different forms of cancer. These drugs can irritate the cells lining the mouth, stomach, and intestines. Many cause nausea, vomiting, and/or diarrhea. All of these can affect nutrient status.
Methotrexate reduces availability of the B vitamin folic acid. Supplementation of folic acid may be recommended for people taking this drug, but ask your doctor before starting folic acid.

\section{Diuretic}

Diuretics cause the body to excrete more urine and are often used to treat high blood pressure and fluid buildup. Some diuretics increase urine losses of minerals such as potassium, magnesium, and calcium. Others limit mineral loss (especially potassium). It is important to talk with your doctor about whether you need to take or avoid mineral supplements.

\section{Laxative}

Laxatives speed up the movement of materials through the digestive tract. This reduces the time for nutrient absorption. Excessive use of laxatives can deplete vitamins and minerals needed for normal body function. Laxatives also increase fluid losses. This may lead to dehydration.

\section{Lipid Lowering Drugs}

Lipid lowering drugs, also called Antihyperlipemic drugs reduce blood cholesterol levels. Medications such as cholestyramine (Questran) may decrease the absorption of the fat soluble vitamins (A, D, $\mathrm{E}$, and $\mathrm{K}$ ), vitamin $\mathrm{B}_{12}$, folic acid, and calcium. For long-term use, it may be helpful to take a multivitamin and a calcium supplement.

\section{Mental Health Drugs}

Psychotherapeutic drugs treat depression, anxiety, and other mental health conditions. Some of these drugs increase appetite while others decrease it. Either effect can impact weight in a significant way. 
Avoid alcohol when using these drugs.

Alcohol can intensify the drowsiness caused

by this class of drugs. Some

psychotherapeutic drugs are Monoamine

Oxidase (MAO) inhibitors (see box).

\section{MAO Inhibitors}

These drugs decrease the body's use of compounds called monoamines. MAO inhibitors can also react with tyramine (a monoamine) found in foods. This reaction can cause a dangerous rise in blood pressure. If not treated, this can cause death. Some aged and fermented foods are high in tyramine. They should be avoided by people taking MAO inhibitors. A few of these foods are:

- aged cheese

- Brewer's yeast, yeast extracts

- Chianti wine

- pickled herring

- fava beans

If you are not sure if you are taking a MOA inhibitor, ask your doctor or pharmacist.

Table 1 and Table 2 include major food/drug and drug/nutrient interactions. This is only a sample of the medications and interactions in each category. Check with your doctor or pharmacist for specific information about your medication. 


\begin{tabular}{|c|c|c|c|}
\hline Drug Class & Food that Interacts & Effect of the Food & What to Do \\
\hline $\begin{array}{l}\text { Analgesic } \\
\text { acetaminophen (Tylenol) }\end{array}$ & Alcohol & Increases risk for liver toxicity & Avoid alcohol \\
\hline \multicolumn{4}{|l|}{ Antibiotic } \\
\hline$\Rightarrow$ tetracyclines & $\begin{array}{l}\Rightarrow \text { Dairy products; iron } \\
\text { supplements }\end{array}$ & $\begin{array}{l}\Rightarrow \text { Decreases drug } \\
\text { absorption }\end{array}$ & $\begin{array}{l}\Rightarrow \text { Do not take with milk. } \\
\text { Take } 1 \text { hour before or } 2 \\
\text { hours after food/milk. }\end{array}$ \\
\hline $\begin{array}{l}\Rightarrow \text { amoxicillin, penicillin, } \\
\text { zithromax, erythromycin }\end{array}$ & $\Rightarrow$ Food & $\begin{array}{l}\Rightarrow \text { Decreases drug } \\
\text { absorption }\end{array}$ & $\begin{array}{l}\Rightarrow \quad \text { Take } 1 \text { hour before or } 2 \\
\text { hours after meals. }\end{array}$ \\
\hline $\begin{aligned} \Rightarrow & \text { nitrofurantoin } \\
& \text { (Macrobid) }\end{aligned}$ & $\Rightarrow$ Food & $\begin{array}{l}\Rightarrow \text { Decreases GI distress, } \\
\text { slows drug absorption }\end{array}$ & $\Rightarrow$ Take with food or milk. \\
\hline $\begin{array}{l}\text { Anticoagulant } \\
\text { warfarin (Coumadin) }\end{array}$ & Foods rich in Vitamin $\mathrm{K}$ & Decreases drug effectiveness & $\begin{array}{l}\text { Limit foods high in Vitamin K: } \\
\text { liver, broccoli, spinach, kale, } \\
\text { cauliflower, and Brussels sprouts }\end{array}$ \\
\hline \multirow{2}{*}{$\begin{array}{l}\text { Anticonvulsant } \\
\text { phenobarbital, primidone }\end{array}$} & Alcohol & Causes increased drowsiness & Avoid alcohol \\
\hline & Vitamin C & Decrease in drug effectiveness & Avoid excess vitamin $C$ \\
\hline $\begin{array}{l}\text { Antifungal } \\
\text { griseofulvin (Fulvicin) }\end{array}$ & High-fat meal & Increases drug absorption & Take with high-fat meal \\
\hline
\end{tabular}




\section{Table 1: Examples of Food/Drug Interactions}

\begin{tabular}{|c|c|c|c|}
\hline Drug Class & Food that Interacts & Effect of the Food & What to Do \\
\hline $\begin{array}{l}\text { Antihistamine } \\
\text { diphenhydramine } \\
\text { (Benadryl), } \\
\text { chlorpheniramine } \\
\text { (Chlor-Trimeton) }\end{array}$ & Alcohol & Increased drowsiness & Avoid alcohol \\
\hline $\begin{array}{l}\text { Antihyperlipemic } \\
\text { lovastatin (Mevacor) }\end{array}$ & Food & Enhances drug absorption & Take with food \\
\hline $\begin{array}{l}\text { Antihypertensive } \\
\text { felodipine (Plendil), nifedipine }\end{array}$ & Grapefruit juice & Increases drug absorption & $\begin{array}{l}\text { Consult your physician or } \\
\text { Pharmacist before changing diet }\end{array}$ \\
\hline \multirow{2}{*}{$\begin{array}{l}\text { Anti-inflammatory } \\
\text { naproxen (Naprosyn), } \\
\text { ibuprofen (Motrin) }\end{array}$} & $\Rightarrow$ Food or milk & $\Rightarrow$ Decreases GI irritation & $\Rightarrow$ Take with food or milk \\
\hline & $\Rightarrow$ Alcohol & $\begin{array}{l}\Rightarrow \text { Increases risk for liver } \\
\Rightarrow \text { Damage or stomach } \\
\text { bleeding }\end{array}$ & $\Rightarrow$ Avoid alcohol \\
\hline $\begin{array}{l}\text { Diuretic } \\
\text { spironolactone (Aldactone) }\end{array}$ & Food & Decreases GI irritation & Take with food \\
\hline $\begin{array}{l}\text { Psychotherapeutic } \\
\text { MAO inhibitors: } \\
\text { isocarboxazid (Marplan), } \\
\text { tranylcypromine (Parnate), } \\
\text { phenelzine (Nardil) }\end{array}$ & $\begin{array}{l}\text { Foods high in tyramine: aged } \\
\text { cheeses, Chianti wine, pickled } \\
\text { herring, Brewer's yeast, fava } \\
\text { beans }\end{array}$ & Risk for hypertensive crisis & Avoid foods high in tyramine \\
\hline
\end{tabular}




\section{Table 2: Examples of Drug/Nutrient Interactions}

\begin{tabular}{|c|c|c|c|}
\hline Drug Class & Food that Interacts & Effect of the Food & What to Do \\
\hline $\begin{array}{l}\text { Acid Blocker } \\
\text { ranitidine (Zantac), } \\
\text { cimetidine (Tagamet), } \\
\text { famotidine (Pepcid), } \\
\text { nizatidine (Axid) }\end{array}$ & Vitamin $\mathrm{B}_{12}$ & Decrease vitamin absorption & $\begin{array}{l}\text { Consult your physician } \\
\text { regarding } \mathrm{B}_{12} \text { supplementation }\end{array}$ \\
\hline $\begin{array}{l}\text { Antihyperlipemic } \\
\text { cholestyramine (Questran), } \\
\text { colestipol (Colestid) }\end{array}$ & $\begin{array}{l}\text { Fat soluble vitamins } \\
(\mathrm{A}, \mathrm{D}, \mathrm{E}, \mathrm{K})\end{array}$ & Decreases vitamin absorption & $\begin{array}{l}\text { Include rich sources of these } \\
\text { vitamins in the diet }\end{array}$ \\
\hline $\begin{array}{l}\text { Antineoplastic } \\
\text { methotrexate }\end{array}$ & Folic acid, vitamin $B_{12}$ & Decreases vitamin absorption & $\begin{array}{l}\text { Consult your physician } \\
\text { regarding supplementation }\end{array}$ \\
\hline $\begin{array}{l}\text { Diuretic } \\
\text { furosemide (Lasix), } \\
\text { hydrochlorothiazide (HCTZ) }\end{array}$ & Many minerals & Increases mineral loss in urine & $\begin{array}{l}\text { Include fresh fruits and } \\
\text { vegetables in the diet }\end{array}$ \\
\hline $\begin{array}{l}\text { Laxative } \\
\text { fibercon, Mitrolan }\end{array}$ & Vitamins and minerals & Decreases nutrient absorption & $\begin{array}{l}\text { Consult your physician } \\
\text { regarding supplementation }\end{array}$ \\
\hline
\end{tabular}




\begin{tabular}{|c|c|}
\hline Class & Used to treat. . . \\
\hline Analgesic & Pain \\
\hline Antacid, Acid Blocker & Stomach upset, ulcers \\
\hline Antibiotic & Infection \\
\hline Anticoagulant & Blood clots \\
\hline Anticonvulsant & Seizures, epilepsy \\
\hline Antihistamine & Allergies \\
\hline Antihyperlipemic & High blood cholesterol \\
\hline Antihypertensive & High blood pressure \\
\hline Anti-inflammatory & Fever, inflammation \\
\hline Antineoplastic & Cancer \\
\hline Diuretic & Water retention \\
\hline Laxative & Constipation \\
\hline Psychotherapeutic & Depression, anxiety \\
\hline
\end{tabular}




\section{Things to Keep in Mind}

As you probably know, there are a wide variety of medications on the market today. Almost all medications have the potential to cause side effects. Many people take more than one medication. This is especially true with older people. When people take multiple medications, food and drug interactions are more likely to occur. The following tips can help you avoid problems with your medication.

- Always carry a list of all your medications and the dosing instructions.

- When your doctor prescribes a new medication, tell him/her all the other drugs you already take. This includes over-the-counter drugs and supplements that you use regularly. Also, remind your doctor about any drug allergies you have.

- Know how and when to take all of your medications. If you have any questions, ask your doctor or pharmacist.

- If you have any side effects from a medication, contact your doctor or pharmacist immediately. Do not wait until your next appointment. If you are not sure if symptoms are related to your medication, be sure to ask.

- It is usually best to take medication with a full glass of water. This may help to prevent stomach irritation and improve absorption. Don't take medications with soft drinks or grapefruit juice.

- Get your prescription refilled before you run out so that there are no missed doses.

- Don't stir your medication into food or drink unless your doctor or pharmacist tells you to. Certain foods may break down the drug, or limit its absorption.
- Always read the directions and warning labels on your medication bottles and packages. If you don't understand something, ask your doctor pharmacist.

\section{References}

\section{Drug Information}

Drug-Nutrient Resource, $5^{\text {th }}$ ed. Roche Dietitians, L.L.C., Riverside, IL. 2003.

Physician's Desk Reference $63^{\text {rd }}$ ed. Thomson Healthcare, Montvale, NJ. 2009.

\section{Food/Drug and Drug/Nutrient Interactions}

McCabe, B.J., Frankel, E.H., Wolfe, J.J., eds. Handbook of Food-Drug Interactions. CRC Press, Boca Raton, FL. 2003.

Akamine, D., Filho M.K., \& Peres, C.M. "Drugnutrient interactions in elderly people.” Current Opinion in Clinical Nutrition and Metabolic Care, 10:304-310, 2007.

Genser, D. "Food and drug interaction: Consequences for the nutrition/health status." Annals of Nutrition \& Metabolism. 52(suppl 1):29-32, 2008.

McCabe, B.J. Prevention of food-drug interactions with special emphasis on older adults. Current Opinion in Clinical Nutrition and Metabolic Care, 7:21-26, 2004.

Important Drug and Food Information. NIH Clinical Center.

http://www.cc.nih.gov/ccc/patient_education/drug nutrient. Accessed 2/8/09.

Food + Drug Interactions. 2004. National Consumers League. http://www.nclnet.org/publications/foodanddrugin t.pdf. Accessed 1/31/09. 